\title{
Islam dan Pluralitas Paham Ekonomi
}

\author{
Oleh: Addiarrahman*
}

\begin{abstract}
This article aims to explore the relationship between Islam (Islamic economy) and many different economic thoughts existing in the world. Islamic economy, since its existence, has established what is called superiority claim that lead its followers to blame other economic thoughts, mainly capitalism, socialism, and new classics. The superiority claim has been a boomerang for Islamic economy to establish an economic system based on Qur'an and hadith because of its counter attack from other economic thoughts followers. Using historic-sociologic approach combined with communicative active theory of Jurgen Habermas, the article tries to make a new silaturabim between Islam and economic thoughts to eliminate negative effects of the claim. It concludes that the fall of conventional economic system which is based on existing economic thoughts is an opportunity for Islamic economy to raises as long as its followers have a willing to communicate actively with previously existing economic thoughts.
\end{abstract}

Keywords: Islamic economy, economic thoughts, superiority claim, and communication active theory

\section{Pendahuluan}

Melihat perkembangan Statistik Perbankan Syariah April 2009, tentu kita akan berfikir bahwa ekonomi Islam di Indonesia telah banyak diminati. Bank Umum Syariah, yang pada September 2008 berjumlah 3 bank, kini meningkat menjadi 5 BUS dengan 643 kantor. Peningkatan ini juga dibarengi dengan meningkatnya jumlah Unit Usaha Syariah dan Bank Pembiayaan Rakyat Syariah, masing-masing 25 dengan 255 kantor dan 134 dengan 209 kantor. Jika dijumlahkan, hingga April 2009 terdapat 1.107 Jaringan Kantor Perbankan Syariah Islamic Banking Network)1. Sungguh sebuh perkembangan yang sangat fantastik, terlebih dengan gejolak krisis ekonomi global di penghujung 2008. Para ekonom Islam unjuk kebolehan dengan mengatakan bahwa ini adalah momentum yang tepat untuk ekonomi Islam mengembangkan sayapnya.

Pernyataan seperti itu, pada satu sisi memang terlihat sebagai sebuah sikap optimis. Namun, bila ditilik lebih dalam, menyisakan persoalan-persoalan mendasar yang pelik. "Proses Penyantrian" sebagaimana dikemukakan oleh Gusdur ${ }^{2}$ adalah satu dari sekian banyak persoalan, yang sejak keberadaan bank syari'ah hingga sekarang, agaknya masih jelas terlihat. Atau "Islamisasi kapitaslime," sebagaimana

*Penulis adalah mahasiswa Islamic Studies pada Magister Studi Islam Universitas Islam Indonesia. Email: addiarrahman@gmail.com dan cikalku@yahoo.co.id

${ }^{1}$ Direktorat Perbankan Syari'ah, Statistik Perbankan Syariah Mei 2009, dikutip dari www.bi.go.id pada tanggal 16 Juli 2009

2Abdurrahman Wahid (2006), Islamku, Islam Anda, Islam Kita: Agama, Masyarakat, Negara Demokrasi (Jakarta: The Wahid Institute), p. 191.

\section{La_Riba}

JURNAL EKONOMI ISLAM

Volume III, No. 1, Juli 2009 
yang dilontarkan oleh Robert W. Hefner. ${ }^{3}$ Kritik seperti ini, menurut penulis bukanlah sikap antipati atas keberadaan bank syari'ah. Namun, "institusionalisasi" ekonomi Islam menjadikan ia terkungkung dalam bingkai sistem kapitalistik yang notabene ditolak oleh ekonom Islam. Image bahwa Islam Indonesia adalah "Islam statistik" tentu tidak bisa dielakkan karena memang kita saban hari larut dalam kungkungan statistika. Padahal, sejarah mengajarkan bahwa Islam bisa berkembang bukan karena jumlahnya penganutnya yang banyak, namun karena kualitas keberagamaan umatnya. Daya tarik kualitas, keimanan dan ketaqwaan (penganut Islam) itulah yang menjadikan Islam bisa diterima secara mayoritas. Terlebih dengan kelenturan ajarannya yang bisa berdialektika dengan kondisi sosial masyarakat Indonesia, yang pada dasarnya adalah feodalistik.

Terdapat satu persoalan penting terkait dengan kualitas keberadaan ekonomi Islam di tengah kancah perekonomian dunia pada umumnya dan Indonesia pada khususnya. Bahwa keberadaan praktik perbankan syariah pada mulanya merupakan gejolak yang berasa dari kaum neorevivalis yang menolak praktik bank berbunga dan menyatakan bunga adalah haram, sehingga menginginkan praktik perbankan yang Islami, tidaklah dapat dibantah. Kekayaan minyak para saudagar Timur Tengah pada era 1960 -an juga ikut ambil bagian. ${ }^{4}$ Akan tetapi, dalam perjalanannya - bila dilihat sejak ia berdiri - praktik perbankan syariah, sebagai cikal mencuatnya ekonomi Islam sebagai "sistem ekonomi alternatif" memiliki problem tersendiri yang amat pelik dalam menjalin hubungan dengan sistem-sistem ekonomi yang telah ada - bahkan boleh dikatakan mumpuni. Alih-alih menjalin hubungan, yang muncul adalah berbagai hujatan dilontarkan untuk melihat sisi lemah sistem ekonomi yang ada (yaitu kapitalisme, sosialisme, neo-liberalisme). Ironisnya, setelah menghujat, ekonomi Islam malah kurang diminati. Lebih dari itu, hujatan balik menyerang: "Tak ada perbedaan, bahkan lebih mahal."

Tak bisa dipungkiri, keberadaan ekonomi Islam pada saat ini adalah dalam wilayah keberagaman paham, baik secara internal maupun eksternal. Secara internal, kita mengetahui ada beberapa mazhab ekonomi Islam yang berkembang. Dan itu, pada ranah tertentu terlihat saling berlawan, bahkan saling hujat. Persoalan seperti ini tentu merupakan karakter Islam yang wajar adanya. Namun, kondisi ini bila disikapi dengan antipati satu sama lain, maka akan timbul persoalan yang cukup pelik. Alih-alih bersaing - bila ingin menggunakan kata persaingan - dengan sistem ekonomi yang telah mumpuni (sisi eksternal), debat mazhab ekonomi Islam secara internal belum menemukan titik temu. Ini misalnya terlihat dengan berbagai kritik yang dilontarkan oleh seorang ekonom Islam terhadap ekonom Islam yang lainnya.

Tulisan ini mencoba menjawab dua pertanyaan penting: bagaimanakah pola hubungan yang dimainkan oleh para ekonom Islam dalam rangka membumikan ekonomi Islam di Indonesia dalam lintasan sejarah?; bagaimanakah pola hubungan yang harus dibentuk dalam pluralitas paham ekonomi? Mengapa saya memilih topik ini adalah karena dalam berbagai diskusi, tulisan yang ada belum merekam

${ }^{3}$ Robert W. Hefner (1999), "Islamisasi Kapitalisme: tentang Pembentukkan Bank Islam Pertama di Indonesia", dalam Mark R. Woodward, Ed (1999), Jalan Baru Islam Memetakan Paradigma Mutakhir Islam Indonesia (Jakarta: Mizan), p. 255-281.

${ }^{4}$ Lebih lanjut lihat: Abdullah Saeed (2004), Menyoal Bank. Syariab: Kritik Atas Interpretasi Bunga Kaum NeoRevivalis, terj. (Jakarta: Paramadina).

Volume III, No. 1, Juli 2009 
Addiarrahman: Islam dan Pluralitas Paham Ekonomi

permasalah ini. Padahal persoalan ini boleh dikatakan sangat penting guna mengembangkan ekonomi Islam untuk masa yang akan datang. Dalam tulisan ini, saya memfokuskan perhatian pada pola hubungan pengembangan ekonomi Islam di Indonesia. Ini dimulai sejak ekonomi Islam, tegasnya bank syariah, hadir di Indonesia hingga sekarang. Pendekatan yang saya gunakan dalam tulisan ini adalah pendekatan historis-sosiologis. Dengan analisis deskriptif-interpretatif, saya berharap tulisan ini mampu mengeksplorasi, untuk selanjutnya mereformulasikan pola hubungan antara Islam (ekonomi Islam) dan berbagai bentuk paham ekonomi yang ada dalam konteks keindonesiaan.

\section{Ekonomi Islam: Kebutuhan atau Kepentingan?}

Semua kita mengetahui bahwa Nabi Muhammad sebelum diangkat sebagai Nabi hingga ia wafat adalah seorang pedagang. Kepiawaian dibarengi sikap jujurnya dalam berdagang membuat ia dijuliki al-Amin. Adalah patut bila Siti Khadijah, seorang janda, saudagar yang kaya raya dan pada akhirnya menjadi isteri Nabi yang pertama, menjadikan Nabi sebagai mitra kerja yang solid. Patutlah jika Afzalurahman menulis sebuah buku dengan judul Muhammad Seorang Pedagang.

Setelah Nabi Muhammad SAW wafat, para khulafaurrasyidin, dan para pengikutnya hingga saat ini senantiasa berusaha meneladan kehidupan Nabi. Tentu dengan berbagai cara, pemahaman yang berbeda. Hasilnya, dari berbagai bentuk pemikiran lahir buah pikir mereka terhadap kandungan Alquran dan Hadis. Berkaitan dengan ekonomi, dapatlah dilihat dalam berbagai pemikiran ulama. Mulai dari para sahabat hingga para ekonom muslim kontemporer, meskipun juga ikut dalam perdebatan silang pendapat, pro-kontra, bahkan menolak apa yang sekarang disebut dengan ekonomi Islam. Namun, terlepas dari pro-kontra dan penolakan itu, derasnya arus keinginan umat melakukan aktivitas ekonomi sesuai dengan pedoman Islam patut diapresiasi.

Bukti sejarah itu, menegaskan bahwa dalam Islam, karena praktik dan perilaku Nabi adalah sunah yang patut dicontoh, maka praktik ekonomi Islam itu telah ada sejak dahulunya. Ini juga menjadi bukti sanggahan bagi sementara orang yang beranggapan bahwa ekonomi Islam lahir karena adanya pergolakan revivalisme di Timur Tengah. Jauh sebelum hal itu terjadi, bahkan sebelum Adam Smith mengeluarkan magnum opus-nya, The Theory of Moral Sentiment dan An Inquiry into the Nature and Causes of The Wealth Of Nations, praktik ekonomi yang Islami itu telah ada. Ini juga membantah tesis the great gap yang dilontarkan oleh Joseph Alois Schumpeter (1883-1950). Schumpeter mengabaikan kenyataan sejarah bahwa Islam memiliki andil dan memberikan kontribusi paling berharga dalam perkembangan ekonomi modern. ${ }^{5}$

Karena tuntutan 'ati'u al-llaha wa 'ati'u al-rasul, maka apa yang diwahyukan Allah dalam Alquran dan Hadis dilaksanakan. Ini sebagai bentuk manifestasi keimanan, sebuah sikap penyerahan diri kepada Allah Swt. saja. Atau merupakan

5Baca Arif Hoetoro (2007), Ekonomi Islam::Pengantar Analisis Kesejarahan dan Metodologi, (Malang: Badan Penerbitan Fakultas Ekonomi Universitas Brawijaya). 
Addiarrahman: Islam dan Pluralitas Paham Ekonomi

penukilan kalimat La ilaha illa Allah, Muhammad Rasulullah. Sikap seperti inilah yang disebut-sebut oleh Muhammad Amien Rais sebagai sikap tauhid sosial. Tauhid yang menyertakan seluruh aktivitas kehidupan dalam bingkai ketauhidan, bukan separuh atau sebagian saja. ${ }^{6}$

Apa yang termuat dalam paragraf di atas, menerangkan kepada ketika bahwa terdapat siklus perwujudan sikap keimanan dan ketauhidan seseorang. Ini bila dihubungkan dengan kehidupan ekonomi bisa menjadi contoh yang akan menghantarkan kita kepada jawaban apakah ekonomi Islam itu adalah sebuah kebutuhan atau kepentingan. Dan ini akan membantu kita untuk melihat apakah syariahisasi perbankan yang marak berkembang di Indonesia sekarang ini adalah sebuah kebutuhan atau kepentingan. Berikut penjelasannya:

Pertama, jauh sebelum Islam menjelma menjadi sebuah ad-din di tanah Arab, manusia telah memiliki fitrah untuk memenuhi kebutuhannya. Lebih dari itu, sejak Adam masih berada di surga, Allah Swt. telah memperingatkan dan menggambarkan bagaimana kegiatan ekonomi yang akan dijalaninya di bumi. Yaitu apabila ada pelanggaran yang membuat Adam dilempar dari surga bersama istrinya, Hawa. Untuk itu, baik kita simak firman Allah SWT berikut;

"Maka kami berkata: "Hai Adam, sesunggubnya ini (iblis) adalah musuh bagimu dan bagi istrimu, maka sekali-kali janganlah sampai ia mengeluarkan kamu berdua dari surga, yang menyebabkan kamu menjadi celaka. Sesunggubnya kamu tidak akan kelaparan di dalamnya dan tidak akan telanjang. Dan sesunggubnya kamu tidak akan merasa dahaga dan tidak. (pula) akan ditimpa panas matahari di dalamnya."

Ayat di atas menjelaskan begitu susahnya kehidupan yang akan dilalui Adam untuk memenuhi kebutuhannya, andai saja dia dan istrinya keluar dari surga akibat ulah rayuan iblis. ${ }^{8}$ Ini menjadi pertanda bahwa manusia memiliki kebutuhan yang harus ia penuhi: sandang, pangan, dan papan, sebagaimana termaktub secara implisit dalam ayat di atas.

Kedua, secara teologis, dalam Islam manusia memainkan dualitas peran yang saling berkaitan: peran khilafah (kepemimpinan) dan 'abdullah (pengabdian). Untuk melaksanakan kedua perannya itu, manusia diberikan pedoman berupa Alquran dan penjelasan-penjelasan Nabi saw. berupa sunah. Manusia dituntut untuk terus menggali makna Alquran, baik yang tersirat, tersurat, maupun tersuruk, atau yang dapat dipikirkan, yang tidak dapat dipikirkan, dan yang terlupakan, ${ }^{9}$ sesuai dengan ruang dan waktu di mana manusia itu berada. Ini menegaskan bahwa memahami Alquran bukanlah hak otoriter kaum muslim, atau kelompok atau mazhab teologi atau fiqh. Dualitas peran yang dimainkan itu, dalam proses selanjutnya, bagi mereka yang benar-benar beriman, menjadi sebuah kebutuhan untuk berkata, berbuat, dan bertindak sesuai dengan apa yang terkandung di dalam Alquran. Itu semua

${ }^{6}$ M. Amien Rais (1994), Taubid Sosial: Formula Menggempur Kesenjangan, (Jakarta: Mizan).

${ }^{7}$ QS Thaha [20]: 117-119.

${ }^{8}$ M. Quraish Shihab (2003), Wawasan al-Qur'an: Tafsir Maudbu'i Atas Pelbagai Persoalan Umat (Bandung: Mizan), Cet. Ke-16. p. 402.

${ }^{9}$ Muhammad Arkoun (1997), Berbagai Pembacaan Al-Qur'an, terj. (Jakarta: INIS).

Volume III, No. 1, Juli 2009 
Addiarrahman: Islam dan Pluralitas Paham Ekonomi

bertujuan mewujudkan integritas antara dualitas yang ada, khilafah dan 'abdullah atau normatif dan historis ${ }^{10}$ atau Ada dan Waktu. ${ }^{11}$

Ketiga, walaupun telah menjadi sebuah kebutuhan, kefanaan waktu menjadikan manusia memiliki kepentingan yang dalam bahasa Alquran disebut sebagai kegandrungan atau tegasnya nafsu yang buruk. ${ }^{12}$ Ini akan terus berkait dalam kehidupan manusia. Oleh karenanya, pada satu titik tertentu akan sulit untuk mengatakan bahwa ini adalah kebutuhan atau kepentingan. Oleh karenanya pada tahap ini, seorang muslim diharapkan mampu mewujudkan ketauhidannya dalam realitas sosial, bukan sekedar ritual ibadah. Ini merupakan upaya agar tidak terjadi pemisahan dualitas, sebagaimana yang telah dijelaskan sebelumnya. Sebagai bentuk pengakuan bahwa manusia membutuhkan spiritualitas, juga menjadi alasan kuat mengapa hal ini diperlukan. Apa yang terjadi pada era post-modernisme ini adalah bukti bahwa harus ada titik balik peradaban karena telah percampurbauran kebutuhan dan kepentingan itu. Terlebih hal itu terjadi manakala para filosof modern, misal Rene Descrates, memisahkan dualitas kehidupan manusia.

Ironisnya, dalam proses pertumbuhan menjelang menginjak usia baligh praktik ekonomi Islam di Indonesia diwarnai dengan pergumulan berbagai kepentingan. Ini tentunya sebuah kewajaran karena, mencuatnya praktik ekonomi Islam di Indonesia sendiri adalah buah dari kepentingan politik rezim Orde Baru. Mulai melemahnya dukungan militer memaksa rezim Orde Baru untuk mengambil simpati massa umat Islam. ${ }^{13}$ Pada satu sisi, hal ini menguntungkan karena kerja keras tokoh-tokoh yang tulus untuk mengembangkan ekonomi Islam akhirnya menuai hasil. Namun, di sisi lain hal ini merupakan pertanda buruk. Berbagai catatan sejarah umat Islam memberitakan bahwa segala bentuk kebijakan yang diboncengi kepentingan politik kekuasaan menuai buah yang pahit. Kehancuran itulah buah yang harus ditelan.

\section{Membaca Indonesia, Menyibak Praktik Ekonomi Islam}

Islam masuk ke Indonesia pada saat kehidupan feodalisme telah mendarah daging pada rakyatnya. Tradisi kerajaan Hindu-Budha yang selama itu menguasai Indonesia menyisakan bekas-bekas feodalistik yang sulit untuk dihilangkan, bahkan hingga saat ini. Kuatnya tirani feodalisme ini masih terus bergulir hingga kerajaan Islam berkembang, tentu tidak terlepas dari intrik politik kekuasaan. Inilah yang membuat Tan Malaka dalam tulisannya Aksi Massa sangat menentang feodalisme yang kemudian dilanjutkan oleh kapitalisme. Bagaimana Islam masuk dan pada akhirnya menjadi agama mayoritas di Indonesia belum ada sebab jawaban yang konklusif. ${ }^{14}$ Oleh karenanya, ada baiknya kita menyimak bagaimana pergulatan awal

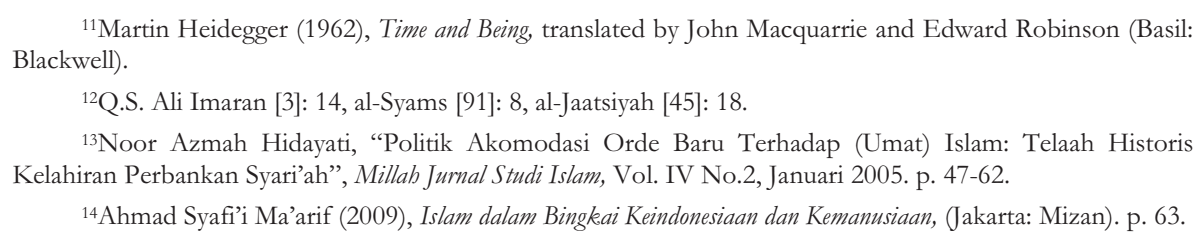
Blackwell).

${ }^{11}$ Martin Heidegger (1962), Time and Being, translated by John Macquarrie and Edward Robinson (Basil:

${ }^{12}$ Q.S. Ali Imaran [3]: 14, al-Syams [91]: 8, al-Jaatsiyah [45]: 18.

${ }^{13}$ Noor Azmah Hidayati, "Politik Akomodasi Orde Baru Terhadap (Umat) Islam: Telaah Historis Kelahiran Perbankan Syari'ah”, Millah Jurnal Studi Islam, Vol. IV No.2, Januari 2005. p. 47-62.

${ }^{14}$ Ahmad Syafi'i Ma’arif (2009), Islam dalam Bingkeai Keindonesiaan dan Kemanusiaan, (Jakarta: Mizan). p. 63.

${ }^{10}$ M. Amin Abdullah (2002), Studi Agama: Normatifitas atau Historisitas?, (Yogyakarta: Pustaka Pelajar). 
masuknya Islam di bumi Nusantara ini. Namun, sebelumnya perlu pula saya kemukakan beberapa teori tentang tahapan perkembangan Islam di Nusantara.

Azhar Arsyad dalam buku Menjadi Indonesia: 13 Abad Eksistensi Islam di Bumi Nusantara menulis, bahwa, menurut Noorduyn, proses masuknya Islam ke Indonesia pada umumnya meliputi tiga tahapan: a. Tahap kedatangan Islam, b. Tahap penerimaan Islam, dan c. Tahap penyebaran Islam lebih lanjut. Sementara itu, Mukti Ali menyebut tahapan lain secara lebih spesifik, yaitu tahap pertumbuhan kerajaan-kerajaan Islam. Dengan kata lain proses masuknya Islam ke kepulauan nusantara meliputi aspek-aspek kontak pertama Islam dengan berbagai wilayah Nusantara, penerimaan Islam oleh penduduk atau kerajaan-kerajaan setempat, penyebaran secara meluas, dan pertumbuhan kerajaan-kerajaan Islam. ${ }^{15}$

Abdul Hadi W.M. mencatat ada enam tahap perkembangan Islam dan transformasi budayanya hingga akhir abad ke-20 $\mathrm{M}^{16}$ : tahap pertama, yang berlangsung sekitar awal abad ke-13 $\mathrm{M}$ hingga pertengahan abad ke-15 M, adalah tahapan yang disebut pemelukan Islam secara formal. Dalam tahap ini yang ditekankan adalah pengenalan kosmopolitanisme Islam, ketentuan-ketentuan dasar pelaksanaan syariah dan fiqh; tahap kedua, bermula pada akhir abad ke-15 M hingga akhir abad ke-16 M, adalah tahapan derasnya proses Islamisasi dan tersebarluasnya Islam di berbagai pelosok kepulauan nusantara; tahap ketiga, berlangsung pada abad ke-17 M, adalah tahapan penyempurnaan pemahaman ajaran Islam dan tradisi intelektualnya; tahap keempat, pada abad ke-18 s.d abad ke-19, terjadi proses ortodoksi atau penekanan terhadap syariah, sehingga berdampak besar terhadap perkembangan tarikat dan mendorong lahirnya antikolonial yang merata di seluruh Nusantara; tahap kelima, munculnya gerakan pembaruan (tajdid). Gerakan-gerakan keagamaan tumbuh menjadi gerakan kebangsaan, seperti SI (Sarekat Islam); tahap keenam, berlangsung sejak 1970-an, setelah memudarnya gerakan pembaruan.

Mengenai teori masuknya Islam ke Indonesia ada beberapa teori yang berkembang. ${ }^{17}$ Namun, terlepas dari plus minus teori yang ada, adalah menarik keterangan M. Dawan Rahardjo yang menggunakan teori perdagangan dan menjelaskan bahwa penyebaran Islam ke kepualauan Nusantara dilakukan melalui perdagangan, masuk secara damai, karena yang menyebarkan Islam adalah para pedagang dan bukan kelas keagamaan semacam pendeta. ${ }^{18}$ Sebagai pedagang, kaum muslim mempunyai kesadaran yang tinggi tentang hak milik. Sebab, tanpa pengakuan akan hak milik itu mereka tidak bisa berdagang. Lebih lanjut M. Dawan Rahardjo memaparkan;

${ }^{15}$ Komaruddin Hidayat dan Ahmad Gaus AF (Ed.) (2006), Menjadi Indonesia: 13 Abad Eksistensi Islam di Bumi Nusantara, (Jakarta: Mizan), p. 75.

${ }^{16} \mathrm{Ibid}$, p. 451-453.

${ }^{17}$ Menyangkut kedatangan Islam di Nusantara, terdapat diskusi dan perdebatan panjang di antara para ahi mengenai tiga masalah pokok: tempat asli kedatangan Islam, para pembawanya, dan waktu kedatangannya. Lihat lanjut lihat, Azyumardi Azra (1998), Jaringan Ulama Timur Tengah dan Kepulauan Nusantara Abad XVII dan XVIII, (Jakarta: Mizan), cet. ke-4, p. 24. Lihat juga, M. Abdul Karim (2007), Sejarah Pemikiran dan Peradaban Islam, (Yogyakarta: Pustaka Book Publisher), p. 323.

${ }^{18}$ M. Dawam Rahardjo (1999), Islam dan Transformasi Sosial-Ekonomi, (Jakarta: LSAF), p. 55. 
Addiarrahman: Islam dan Pluralitas Paham Ekonomi

"...Kesadaran akan hak milik mulai melemah ketika Islam masuk ke pedalaman pedesaan dan menyebar di kalangan masyarakat petani yang bidup dalam sistem feodal, di mana tanah dan sumber daya alam lainnya adalab milik raja. Kesadaran itu menjadi semakin melemah dengan masuknya sistem Tanam Paksa, di mana pemerintah kolonial menguasai sumber daya alam melalui penguasaan sumber daya manusianya, yakni tenaga kerja petani. Dalam sistem ekonomi dan sistem politik ini Islam mengalami penyesuaian. Dengan penyesuaian itu, kemurnian Islam memang berkurang, tetapi Islam berkembang menjadi agama rakyat (folks-religion). Inilah yang menimbulk.an apa yang oleh Gellner disebut sebagai "Low Islam" atau Islam Rendah yang lebih emosional, mistik dan kolektif'19.

Apa yang dikemukakan oleh M. Dawan Rahardjo tersebut, memiliki nada dan irama yang sedikit berbeda dengan keterangan yang diberikan Ahmad Syafi'i Ma'arif. Ia menjelaskan:

"...Seperti umum telah sedikit dimaklumi babwa perkembangan Islam di Nusantara berkait erat dengan dunia perdagangan. Dunia perdagangan adalah sebuah dunia yang sangat dinamis dan egalitarian. Pesisir Jawa dengan kota-kota pelabuhannya telah membangun jaringan perdagangan dengan Malaka, Pasai, Benggala, Gujarat, dan babkan dengan Iran yang sudab lama bercorak Islam. Para pedagang umumnya adalah manusia kreatif yang peka dalam mengikuti angin perubahan, termasuk perubahan dalam sistem nilai. Sistem sosial dalam bentuk kasta sangat menghambat gerak yang dinamis itu, apalagi bangsawan Hindu-Budha memandang perdagangan sebagai sesuatu yang rendah. Islam sejak masa dini malah digerakean pertama kali oleh seorang Nabi yang sebelumnya jadi pedagang. Maka tidak mengherankan kemudian bahwa Islam dinilai memberi dorongan kuat kepada para pedagang untuk memperluas radius komunikasinya dengan pusat-pusat komersial yang telah dikuasai Islam itu. Adapun belakangan umat Islam keok di dunia perdagangan, itu tentu disebabkan bilangnya kepekaan dan etos wiraswasta dari diri mereka.'20

Keterangan-keterangan sejarah yang dijelaskan oleh kedua tokoh tersebut, menerangkan kepada kita betapa pola hubungan yang dijalin oleh para pedagang Islam dengan penduduk pribumi Indonesia mampu mempengaruhi mereka sehingga menjadi yakin dan mengimani Islam, meskipun Islam yang dikembangkan adalah Low Islam karena itu memang sesuai dengan kondisi sosilogis rakyat Nusantara pada saat itu. Agaknya, pengaruh Hindu-Budha adalah penyebabnya, sebagaimana telah disebutkan.

Hubungan Islam dan ekonomi dalam lintas sejarah Indonesia, mulai mendapat tekanan sejak kolonialisme masuk ke Indonesia. Pada satu sisi, memang hal itu berpengaruh secara signifikan. Di sisi yang lain, masuknya para koloni dengan membawa proyek Kristenisasi (gospel), di samping tujuan lainnya (gold and glory), mempercepat proses Islamisasi di Indonesia. ${ }^{21}$ Masuknya Belanda dengan

${ }^{19}$ Ibid.

${ }^{20}$ Ahmad Syafi'i Ma'arif, Op. Cit. p. 74.

${ }^{21}$ Ibid. p. 80. 
Addiarrahman: Islam dan Pluralitas Paham Ekonomi

proyek pemisahan Islam dari dunia politik (polity) menandai awal dari poses Polityseparation Secularization. ${ }^{22}$

Yudi Latif ketika menjelaskan proses polity-expansion secularization yang dilakukan oleh Belanda menerangkan bahwa:

"Akan tetapi, karena intruksi kolonialisme dan kepentingan para pemimpin nasionalis sekular dalam reformasi ekonomi, yurisdiksi polity telah meluas hingga mencakup relasi-relasi ekonomi yang sebelumnya dianggap sebagai wilayah suci dan tak bisa disentuh. Jika bukum dagang telah sepenuhnya tersekularisasikan, lenyapnya yurisdiksi Islam atas soal warisan pada 1937 (diklaim kembali pada 1989), yang mana pun dianggap sebagai inti konsern keagamaan bagi Muslim...'”3

Yang menarik adalah Yudi Latif melanjutkan penjelasannya dengan memberikan sebuah renungan yang hingga saat ini agaknya belum bisa terjawab. Ia menjelaskan bahwa dukungan MUI dan ICMI dalam pendirian Bank Muamalat Indonesia menandakan bahwa ide tentang ekonomi yang beroreintasi Islam telah kembali bergema. Namun, lanjut Latif, apakah bentuk-bentuk ekonomi ramah agama itu bisa bertahan menghadapi gempuran hebat dari ekonomi sekular berbasis pasar bebas, masih ditunggu pembuktiannya. ${ }^{24}$

Sejak terjadinya sekularisasi ekonomi, kemudian usaha kembali memasukkan ide ekonomi ramah agama, dan berjamurnya bank-bank Islam di Indonesia dengan berbagai turunannya, seperti BMT, asuransi syariah, dan lainnya, terdapat perbedaan yang cukup signifikan bagaimana hubungan Islam dalam dunia ekonomi. Terlebih dengan kondisi sekarang yang boleh dikatakan berbagai paham ekonomi telah berkembang dan menjadi pegangan masing-masing negara yang ada di dunia. Di Indonesia sendiri, telah banyak paham ekonomi yang berkembang, mulai dengan kapitalisme yang diajarkan oleh para penjajah, kemudian ditentang oleh Soekarno-Hatta dengan ekonomi rakyatnya, dan dilanjutkan oleh Soeharto dengan ekonomi Pancasila yang berbaju militer dan terakhir ekonomi campuran yang berkembang sejak reformasi hingga saat ini. Terlebih dengan mencuatnya neoliberalisme yang mencekam Indonesia. ${ }^{25}$ Perbedaan pola hubungan itu tentunya tidak terlepas dengan kondisi sosial masyarakat Indonesia. Pada saat pertama masuk, Islam lebih bercorak feodalisme dan berusaha mencari perlindungan kungkungan feodalisme yang menindas hak milik, dan kondisi masyarakat yang telah terbiasa, bahkan telah mendarah daging dengan budaya konsumerisme yang pada dasarnya merupakan basis kapitalisme. Bila masa awal rakyat sekedar terjerat feodalisme, maka kondisi sekarang, di samping pengaruh feodalisme yang masih belum hilang, ditambah dengan budaya konsumerisme (kapitalisme).

${ }^{22}$ Polity-separation secularization adalah satu dari empat karekteristik sekulerisasi yang dikembangkan oleh Donald E. Smith. Tiga lainnya adalah: polity-expansion secularization; polity-transvaluation secularization; dan politydominance secularization. Lebih lanjut lihat. Donald E. Smith (1970), Religion and Political Development, (Boston: Little, Brown and Company).

${ }^{23}$ Yudi Latif (2007), Dialektika Islam: Tafsir Sosiologis Atas Sekularisasi dan Islamisasi di Indonesia, (Yogyakarta: Jalasutra). p. 34

${ }^{24}$ Ibid. p. 35.

${ }^{25}$ Lebih lanjut baca: Awalil Rizki dan Nasyith Majidi (2008), Neoliberalisme Mencengkeram Indonesia, (Jakarta: E Publishing).

Volume III, No. 1, Juli 2009 
Addiarrahman: Islam dan Pluralitas Paham Ekonomi

Pada saat Islam masuk, para pedagang Muslim memperlihatkan sikap egalitarian, dinamis dan persamaan hak. Sikap seperti ini menarik perhatian masyarakat Indonesia. Proses menjadi muslim secara formal dan kosmopolitan pun terjadi. Rakyat merasa senang dengan pengakuan hak atas tanah yang diberikan oleh pedagang Islam yang pada tahap selanjutnya membangun kerajaan. Ini terus terjadi hingga kolonialis tiba. Pergolakan kembali muncul manakala berdirinya Serikat Dagang Islam kemudian berubah menjadi Sarikat Islam (SI) pada tahun 1912, Muhammadiyah (1912), dan beberapa organisasi lainnya. Pola hubungan yang dijalankan lebih revolusioner. Berbagai pembaharuan dilakukan. Namun, sayangnya etika politik para elit politik sejak era kemerdekaan hingga Orde Baru berkuasa menekan laju pergerakan Islam lewat berbagai organisasi. Baik di bidang perdagangan pun partai politik. Pada tahap ini, pola hubungan yang dilakukan lebih pada tataran akar rumput yang dengan etos nerimo-nya. Barulah pada saat reformasi digulirkan dan rezim Soeharto turun, gerakan syariah minded bangkit kembali. Kelompok-kelompok gerakan Islam syariat pun dibentuk. Tuntutan kembali kepada Piagam Jakarta pun dilakukan. ${ }^{26}$ Sayangnya, pergerakan ini diboncengi dengan rigiditas dari kelompok gerakan Islam syariat yang notabene merupakan basis pelebaran sayap kelompok Wahabi. ${ }^{27}$ Meskipun pada dasarnya praktik ekonomi Islam di Indonesia tidaklah dimotori oleh kelompok konservatif, ${ }^{28}$ pengaruh gerakannya cukup kuat. Terlebih setelah munculnya gerakan Islam syariat itu juga dibarengi dengan berdirinya kelompok Islam liberal yang menolak mentah apa yang disebut dengan ekonomi Islam.

Adalah patut kita menjawab bagaimanakah pola hubungan atau silaturrahim Islam dan ekonomi dalam ranah yang pluralis ini? Terlebih dengan kondisi masyarakatnya yang terlanjur cinta dengan praktik ekonomi yang entah disadari atau tidak, merupakan bagian kapitalisme? Apakah dengan mengatakan bahwa segala bentuk sistem ekonomi yang ada itu adalah fasid, buruk dan harus diganti dengan yang Islami? Sebelum menjawab, saya mencoba mereformulasikan pola hubungan atau silaturahim Islam dan ekonomi dalam ranah pluralitas Indonesia. Ada baiknya juga sedikit saya paparkan kelemahan yang selama ini terjadi dalam pengembangan ekonomi Islam di Indonesia, atau mungkin di dunia, atau apa yang saya sebut dengan klaim superioritas paham ekonomi.

\section{Klaim Superioritas Paham Ekonomi}

Syofyan Syafri Harahap pada waktu seminar nasional ekonomi Islam, dengan tema "Kontribusi Ekonomi Islam dalam Menanggulangi Krisis Ekonomi Global,"

${ }^{26}$ Haedar Nashir menyebut gerakan ini dengan istilah "Gerakan Islam Syariat". Lihat Haedar Nashir (2007), Gerakan Islam Syariat: Reproduksi Salafiah Idiologis di Indonesia, (Jakarta: PSAP).

${ }^{27}$ Abdurrahman Wahid. (Ed.)(2009), Ilusi Negara Islam: Ekspansi Gerakan Islam Transnasional di Indonesia, (Jakarta: Gerakan Bhineka Tunggal Ika, The Wahid Institute, dan Maarif Institute). Lihat pula. Greg Fealy dan Anthony Bubalo (2007), Jejak. Kafilah: Pengaruh Radikalisme Timur Tengah di Indonesia, (Jakarta: Mizan).

${ }^{28}$ Tokoh-tokoh yang terlibat dalam pendirian bank syariah di Indonesia adalah; Karnean A. Perwataatmadja, M. Dawam Rahardjo, A.M. Saefuddin, M. Amien Rais, dan lain-lain, lebih lanjut lihat. Muhammad Syari'i Antonio (2001). Bank Syari'ab Dari Teori Ke Praktik (Jakarta: Gema Insani). p. 25. 
Addiarrahman: Islam dan Pluralitas Paham Ekonomi

pada tanggal 18 Desember 2008, dengan lantangnya mengatakan bahwa ekonomi kapitalis adalah "ekonomi setan." Patut diberikan apresiasi atas keberanian itu. Namun, itu belumlah selantang kritikan Umar Ibrahim Vadillo dan Zaim Saidi yang mengatakan Bank Syariah tetap haram. ${ }^{29}$ Dalam berbagai buku, jurnal, diskusi, dan seminar-seminar yang membahas tema ekonomi Islam, bisa dikatakan selalu kita temukan cuplikan bahasan yang menebarkan dan mempertontonkan pesona kelemahan sistem ekonomi yang ada. Selanjutnya, menggembar-gemborkan sistem ekonomi Islam, meskipun juga diakui bahwa ekonomi Islam tidak bisa terlepas begitu saja dari ekonomi konvensional.

Terlepas benar atau salah kritikan yang dilontarkan atau seberapa parah borok yang menjangkiti kapitalisme dan paham ekonomi lainnya, adalah patut kita pikirkan efek dari kritikan sekaligus hujatan itu yang agaknya sering lepas dari pengawasan kita selama ini. Berbagai bentuk kritikan sekaligus hujatan senantiasa dilontarkan terhadap kapitalisme, sosialisme, dan baru-baru ini neo-liberalisme. Namun, efek dari hujatan itu sendiri tidak kita hiraukan. Padahal Allah sendiri secara tegas memperingatkan kepada kita dalam surat al-Hujarat [49] ayat 11, agar jangan pernah merendahkan suatu kaum, karena bisa jadi ia lebih baik dari pada kita.

Agaknya apa yang difirmankan Allah tersebut telah melanda kubu ekonomi Islam sebelum dapat memberikan bukti bahwa ia dapat mensejahterakan umat dan bisa menjadi sistem ekonomi alternatif bagi pemerintah, terlepas dari perkembangan kuantitatif-statistik perbankan syariah. Ini bukanlah untuk memperlihatkan sikap pesimis atau antipati terhadap praktik ekonomi Islam. Tak lebih adalah sebagai bukti dari kelalaian kita dalam memahami firman Tuhan. Share perbankan syariah yang masih berada pada kisaran angka 2,5\% adalah menunjukkan kurang diminatinya praktik ekonomi Islam yang berbasis pada perbankan syariah.

"Karena sempurna justru menjadi lemah", begitu judul makalah Yusdani pada acara Bedah Kitab Ekonomi Islam pada tanggal 18 Juni 2009 yang diselenggarakan oleh Prodi Ekonomi Islam FIAI UII ${ }^{30}$. Tesis yang dijadikan judul makalah ini, dibangun berdasarkan sebuah argumen bahwa karena begitu sempurnanya aksioma-aksioma ekonomi Islam yang dirancang selama ini, menjadikan ia sulit, bahkan menjadi sebuah 'ketidakmungkinan' untuk diterapkan dalam kehidupan masyarakat. Perbedaannya dengan ekonomi konvensional, menjadikan proponen ekonomi Islam lebih superior dan bernilai plus dari pada sistem ekonomi lainnya.

Dari segi akademik, Yusdani menjelaskan, superioritas dan nilai plus ekonomi Islam dibandingkan dengan sistem ekonomi lainnya, menyisakan persoalan mendasar. ${ }^{31}$ Jika benar sistem ekonomi Islam adalah superior dan bernilai plus atau

${ }^{29}$ Umar Vadillo (2005). The End of Economics: an Islamic Critique of Economics, terj. (Jakarta: Pustaka Zaman). Zaim Saidi (2005). Kembali Ke Dinar: Tinggalkan Riba Tegakkan Muamalah (Depok: Pustaka Adina). Zaim Saidi (2007). Ilusi Demokrasi Kritik dan Otokritik Islam: Menyongsong Kembalinya Tata Kehidupan Islam Menurut Amal Madinah, (Jakarta: Republika).

${ }^{30}$ Yusdani, "Karena Sempurna Justeru Menjadi Lemah", Makalah disampaikan pada acara Bedah Kitab Ekonomi Islam yang diselenggarakan oleh Prodi Ekonomi Islam FIAI UII, Kamis, 18 Juni 2009. h., 2.

${ }^{31}$ Ibid.

Volume III, No. 1, Juli 2009 
Addiarrahman: Islam dan Pluralitas Paham Ekonomi

lebih, tentunya ia akan lebih mampu mengatasi masalah dan tantangan peradaban manusia modern. Nyatanya, saat ini, bukanlah sistem ekonomi Islam yang dominan di dunia, bahkan di negara-negara yang mayoritas berpenduduk Muslim. Oleh karena itu, jika sistem ekonomi Islam adalah sistem yang sempurna, mengapa tidak ada rujukan dalam sejarah di mana sistem ini dapat dianggap berhasil dan masih tetap relevan di masa sekarang? Tentunya, tesis yang diajukan oleh Yusdani itu, akan menimbulkan perdebatan panjang. Kesan pelecehan, setidaknya menjadi titik pusat perdebatan itu. Pun demikian, melirik pada tataran akademik, terlebih praktik, apa yang disampaikan oleh Yusdani itu seolah-olah mendapat pengakuan tidak langsung bahwa karena kesempurnaannya ekonomi Islam menjadi lemah.

Sebagaimana telah saya tuliskan pada bagian awal tulisan ini, klaim superioritas paham ekonomi dalam Islam tidak hanya dilontarkan kepada pahampaham ekonomi konvensional (eksternal). Lebih dari itu, juga terhadap mazhabmazhab ekonomi Islam yang berkembang, antara satu dan yang lainnya. Bagi yang mengimani mazhab Baqr Shadr dengan buku induk Iqtishaduna-nya, mazhab ekonomi Islam lainnya dianggap lemah. Salahsatu bentuk klaim superioritasnya adalah bahwa istilah "ekonomi" itu sendiri yang menurut mereka tidak cocok digandengkan dengan kata "Islam". Islam hanya mengenal istilah Iqtishaduna. Ini misalnya terlihat jelas dengan sikap kelompok Hizbut Tahrir, khususnya di Indonesia yang mengklaim kebenaran sistem ekonomi Islam yang diimaninya itu. Tarik ulur klaim kebenaran mazhab ini agaknya memang telah menjadi tradisi dalam dunia Islam. Ini dapat kita lacak dalam lintasan sejarah umat Islam sejak terjadinya peristiwa tabkim antara kelompok Ali dan Mu'awiyah. Berbagai aliran teologis, masing-masing menyatakan diri mereka sebagai kelompok yang paling selamat dari pada yang lain. Berbagai cara dilakukan untuk hal itu. Mulai dari politik pengkafiran ${ }^{32}$ hingga menjatuhkan hukum mati atau bahkan membunuh mereka yang di luar kelompok.

Debat tak berkesudahan klaim superioritas kebenaran paham dalam kelompok-kelompok Islam ini hingga sekarang masih terus berlanjut. Adalah wajar kiranya timbul karya-karya yang menyayangkan sikap seperti itu. Misalnya karya yang ditulis oleh M. Abou El Fadl, Speaking In God's Name: Islamic Law, Authority, and Women, yang diterbitkan oleh Oneworld Publication, Oxford, pada tahun 2003.33 Dalam karyanya itu, dengan tegas Abou El Fadl mengatakan bahwa sikap otoritarianisme merupakan sikap perampasan kewenangan Tuhan selaku pemegang kebenaran mutlak. Ironisnya, ketika umat Islam ingin mengembangkan sistem ekonomi yang berbasiskan kepada nilai-nilai Islam, sikap otoritarianisme ini mencuat dengan hebatnya. Tidak hanya dalam konteks fiqh, bahkan bentuk pengakuan bahwa ekonomi Islam adalah ekonomi yang paling benar. Alih-alih menjadi rahmatan lil 'alamin, dengan sikap superioritas itu sendiri belum mampu meyakinkan umat Islam itu sendiri untuk menabung di bank-bank Islam. Memang akhir-akhir ini umat kristiani di Amerika, Inggris, Belanda, dan beberapa Negara

${ }^{32}$ Muhammed Yunis (2006) Politik Pengkafiran dan Petaka Kaum Beriman, terj. (Yogyakarta: Pilar Media).

${ }^{33}$ Edisi Indonesia baca. M. Abou El Fadl (2004). Atas Nama Tuhan: Dari Fikih Otoriter ke Fikih Otoritatif (Jakarta: Serambi).

66 La_Riba JURNAL EKONOMI ISLAM

Volume III, No. 1, Juli 2009 
Addiarrahman: Islam dan Pluralitas Paham Ekonomi

Eropa dan Asia lainnya, menaruh perhatian terhadap perbankan Islam. Namun perlu dilihat apakah itu dikemas dalam bentuk superioritas paham ekonomi atau tidak, sebagaimana yang lazim ditonjolkan oleh para ekonom Islam di Indonesia dalam berbagai perbincangan baik lisan maupun tulisan.

\section{The New Model Of Silaturrahim: Islam dan Pluralitas Paham Ekonomi}

Sebelum saya memaparkan the new model of silaturabim Islam dan pluralitas paham ekonomi ini, ada baiknya saya mengemukakan beberapa usaha yang telah dilakukan oleh penulis lain. Ada dua tulisan yang menurut saya memberikan sumbangsih yang cukup signifikan.

Pertama, saya sangat mengapresiasi apa yang ditulis oleh Ugi Suharto, Paradigma Ekonomi Konvensional dalam Sosialisasi Ekonomi Islam. ${ }^{34}$ Walau tidak terlalu concern terhadap apa yang saya tulis ini, Ugi mampu meramu resep untuk mensosialisasikan ekonomi Islam dengan menggunakan paradigma ekonomi konvensional. Hanya saja hal ini menjadi titik kelemahan tulisan Ugi. Sebab ia beranjak dari konvensional menuju Islam, bukan sebaliknya. Kesan masih terbingkai dalam paradigma konvensional tetap kuat melekat. Pada posisi ini, tulisan Ugi adalah wajar bila menimbulkan perdebatan. Namun, terlepas dari kelemahan itu, Ugi berhasil memberikan tawaran pendekatan Islamisasi - saya sendiri tidak begitu setuju dengan proyek Islamisasi ini - ekonomi konvensional yang dinilainya adil. Pendekatan yang ditawarkannya adalah 1) Pendekatan Menolak (negation); 2) Pendekatan Memadukan (Integration); dan 3) Pendekatan Menambah Nilai (Value Addition). Pendekatan pertama adalah bagaimana ekonomi Islam mampu berdialektika dengan ekonomi konvensional, melakukan filter, dalam pandangan Umar Chapra. Dengan kata lain, tidak semua paradigma ekonomi konvensional dapat diterima ataupun ditolak. Unsur-unsur sekularisme, faham kebebasan nilai, materialism, dan darwinisme haruslah ditolak. Di sinilah peran pendekatan negation yang diikuti oleh prinsip membuang (elimination). Pendekatan Integration adalah kelanjutan dari dialektika kedua paradigma yang berbeda itu. Dalam hal ini, menarik apa yang dikemukakan Ugi:

\section{"...Begitu juga dengan ilmu ekonomi konvensional, apabila tidak diberikan penilaian yang sewajarnya, atau babkan ditolak secara serampangan begitu saja tanpa ilmu, walaupun atas semangat Islam, maka bisa jadi akan membawa dampak yang sama, yaitu ilmu ekonomi Islam semakin tidak disukai, manakala ilmu ekonomi konvensional akan semakin dicintai. Sudah tentu proses sosialisasi ekonomi Islam akan tersekat dan terhambat dengan sikap yang seperti itu."}

Dan terakhir, adalah kepastian yang tidak bisa dibantah lagi bahwa ekonomi Islam pun memberikan sesuatu yang baru, yang lebih baik, dan yang lebih bermanfaat bagi kehidupan berekonomi umat manusia. Ketiga pendekatan tersebut, menurut Ugi, haruslah diterapkan secara serentak. Tentu harus diikuti pula dengan Islamic worldview, dan peran epistemologi Islam. Sayangnya, pada waktu menjelaskan

${ }^{34}$ Ugi Suharto, "Paradigma Ekonomi Konvensional Dalam Sosialisasi Ekonomi Islam," Journal of the Islamic Economic Forum for Indonesian Development (ISEFID), Volume 3. No.3. 1424/2004, p. 40-57. 
Addiarrahman: Islam dan Pluralitas Paham Ekonomi

peran epistemologi Islam, Ugi terjebak pada sikap antipati terhadap sesuatu yang berasal dari barat. Dengan bahasa Samuel P. Huntington, ia sama saja memperlihatkan sikap the clash of civilization. Seperti penilaian Ugi terhadap pemikiran Muhammad Arkoun yang dinilainya dapat menghilangkan Islam itu sendiri, bila Alquran dibongkar. Padahal cukup jelas kiranya bahwa apa yang dikehendaki Arkoun bukanlah mengganggu gugat kebenaran Alquran, namun bagaimana cara memahami Alquran itu sendiri yang harus didekonstruksi karena tradisi lama telah terbelenggu oleh ragam kepentingan dan terkesan kaku, nonapplicable. 35

Kedua, buku yang ditulis oleh Tim Penulis MSI UII yang berjudul Menjawab Keraguan Berekonomi Syari'ah. ${ }^{36}$ Ada lima point yang dijadikan pijakan sekaligus inti dari buku tersebut, yaitu lima permasalahan yang menjadi keraguan untuk berekonomi syariah: 1) Ekonomi Islam hanyalah sebuah fenomena yang muncul secara reaktif dan karena emosi keagamaan semata; 2) Belum mengetahui dan memahami fundamental dan filosofi penerapan ekonomi Islam dalam kehidupan keseharian; 3) Belum mengetahui dan memahami secara mendasar perbedaan dan keunggulan ekonomi Islam dibanding ekonomi konvensional; 4) Belum mengetahui dan memahami perhitungan matematis keunggulan ekonomi Islam; dan 5) Belum mengetahui proyeksi ketahanan ekonomi Islam dan strategi pengembangan ekonomi Islam. ${ }^{37}$ Pada satu sisi, buku ini mampu memberikan 'pencerahan' bagi mereka yang meragukan eksistensi ekonomi Islam, walaupun masih terbuka peluang untuk diperdebatkan. Hanya saja, di sisi yang lain, dalam beberapa bahasan masih dimulai dengan bahasa celaan atau hujatan terhadap ekonomi konvensional. ${ }^{38}$

Sejak awal tulisan ini, mungkin pembaca akan merasa bahwa saya memiliki sikap anti terhadap segala bentuk bahasa atau tulisan celaan dan hujatan yang dilontarkan kepada ekonomi konvensional. Ini bukan berarti saya ingin menafikan bahwa memang terdapat borok pada ekonomi konvensional. Hanya saja bagaimana kita menyibak borok tersebut dengan pendekatan yang sama, pendekatan konvensional, itu yang harus dilakukan. Seperti buku yang ditulis oleh Mansour Fakih, Teori Pembangunan dan Globalisasi. ${ }^{39}$ Dengan ini, betapapun keras celaan dan hujatan yang dilontarkan, tentu tidak akan ada boomerang yang balik menyerang. Mengapa demikian? Di samping telah tertulis dalam Alquran surat Al-Hujarat [49]: 11, juga adalah sebagai sikap antisipasi untuk melindungi Islam itu sendiri dari hujatan orang lain.

Lalu tawaran seperti apa yang akan saya berikan untuk menjalin silaturahim antara Islam dan pluralitas paham ekonomi yang berkembang saat ini? Dalam hal ini, saya mencoba meminjam teori tindakan komunikatif milik Jürgen Habermas, sebagaimana yang dikembangkan oleh F. Budi Hardiman. Teori Habermas ini, pada

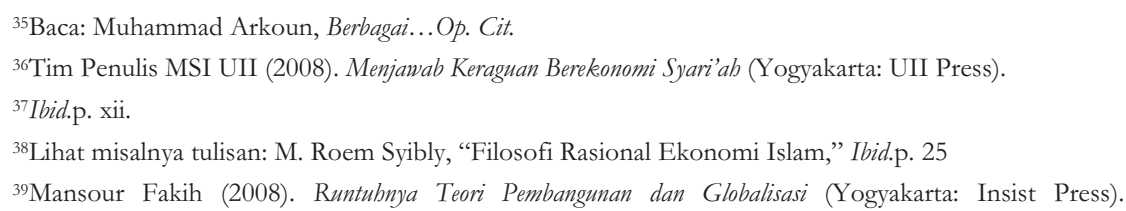


titik tertentu memang akan terkesan liberal atau sekular. Namun, bila dilihat secara seksama ada persamaan dengan teori tindakan komunikatif yang dirumuskan Allah Swt. dalam Alquran surat Al-Hujarat [49] ayat 11 s.d. 13.

Pada dasarnya teori tindakan komunikatif Habermas beranjak dari teori diskursus yang telah lama berkembang. Habermas menolak rasio praktis ala Kant yang dianggapnya bersifat monologal, absolutisme dan totaliter. ${ }^{40}$ Untuk memahami ide tindakan komunikatif Habermas, setidaknya kita harus memahami konsepkonsep dasar yang dikembangkannya: 1) rasio prosedural; 2) tindakan komunikatif dan klaim-klaim kesahihan; 3) Lebenswelt (dunia-kehidupan) sebagai konsep teori komunikasi; 4) Lebenswelt dan sistem; dan 5) Prosedur komunikasi. ${ }^{41}$ Namun, dalam tulisan ini saya tidak akan membahas teori Habermas itu secara keseluruhan.

Inti dari tawaran teori yang dikemukakan Habermas adalah bagaimana adanya hubungan intersubjektif dalam kemajemukan masyarakat. Setiap orang memiliki kepentingan yang berbeda. Kepentingan itu akan menjadi wacana. Bagaimana mendialogkan wacana itu agar tiap-tiap kelompok bisa mencapai tujuan adalah cara dan prosedur yang harus ditempuh, bukan memikirkan tujuan masyarakat. Tujuan itu sendiri pada gilirannya harus disepakati bersama menurut sebuah posedur komunikasi yang tepat. ${ }^{42}$ Dalam hal ini, Hardiman mencontohkan ketika menghadapi wisatawan asing, kita akan berusaha untuk mengerti katakatanya yang diungkapkan dalam bahasa yang asing bagi kita. Dalam upaya-upaya untuk mengerti ini baik kita maupun orang asing memakai berbagai cara dan sarana termasuk isyarat-isyarat non-verbal dan mimic untuk menjelaskan suatu maksud. Kita membayangkan diri kita berada pada posisi orang lain, demikian pula dia. Dengan mencoba mengambil perspektif orang lain, kita dan dia akhirnya dapat saling mengerti. ${ }^{43}$

Lalu bagaimanakah hubungannya dengan klaim superioritas paham ekonomi yang berkembang dalam kubu ekonom Islam? Dalam hal ini menurut Habermas, sebagaimana yang dijelaskan oleh Hardiman, upaya yang harus dilakukan adalah bagaimana tindakan komunikatif itu melahirkan consensus yang rasional. Ini terjadi bila peserta komunikasi dapat menyatakan pendapat dan sikapnya terhadap klaimklaim kesahihan tersebut secara bebas dan tanpa paksaan. Bagaimana mencapainya? Habermas berkata, kerberhasilan komunikasi tergantung kepada pendengan untuk "menerima-atau-menolak" (ja-oder-Nein-Stellungsnahme) klaim-klaim kesahihan itu. Artinya klaim-klaim kesahihan itu harus serantak benar, tepat dan jujur, supaya pendengar dapat mengambil sikapnya. Untuk itu adalah baik kita memperhatikan bagan berikut:

${ }^{40}$ F. Budi Hardiman (2009). Demokrasi Deliberatif: Menimbang Negara Hukum' dan 'Ruang Publik' dalam Teori Diskursus Jürgen Habermas (Yogyakarta: Kanisius). p. 30.

${ }^{41}$ Lebih lanjut baca: F. Budi Hardiman, Ibid. dan masih ditulis oleh F. Budi Hardiman (2009). Kritik Ideologi: Mengingkap Pertautan Pengetahuan dan Kepentingan Bersama Jürgen Habermas (Yogyakarta: Kanisius). Edisi ke-3. Thomas McCarthy (2008). Teori Kritis Jürgen Habermas, terj. (Yogyakarta: Kreasi Wacana). Cet. Ke-2.

${ }^{42}$ F. Budi Hardiman, Demokrasi...p. 24.

${ }^{43}$ Ibid. p. 35.

Volume III, No. 1, Juli 2009 
Addiarrahman: Islam dan Pluralitas Paham Ekonomi

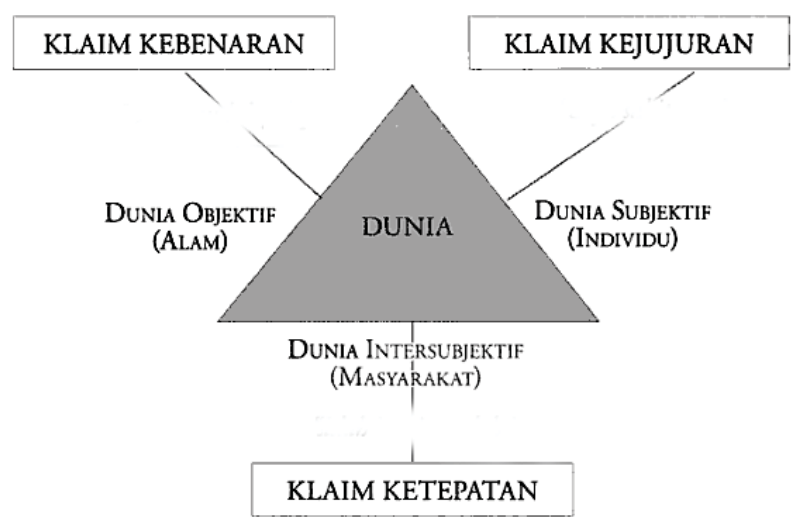

Sumber: F. Budi Hardiman. (2009). Demokrasi Deliberatif: Menimbang 'Negara Hukum' dan 'Ruang Publike' dalam Teori Diskursus Jürgen Habermas. (Yogyakarta: Kanisius). p. 37. Dalam komunikasi diambil tiga macam sikap performatif terhadap dunia. Consensus dapat tercapai hanya jika ketiga klaim kesahihan itu serantak dipenuhi.

Jika ketiga performatif itu dibawa ke ranah pergulatan paham ekonomi maka dapat digambarkan sebagai berikut:

Setiap paham ekonomi boleh mengemukakan klaim-klaimnya dengan satu prinsip saling terbuka, tanpa merasa yang satu lebih superior atas yang lain sehingga ingin mendominasi den menghegemoni. Posisi ekonomi Islam pada ranah dunia intersubjuktif bukanlah sebagai hakim yang memutuskan benar-salah, hitam-putih, halal-haram, terhadap paham ekonominya sendiri, dan paham ekonomi lain. Ini semua karena, saya mengasumsikan ketika ekonomi bergulat di ranah sosial, maka ia bukanlah milik suatu subjek atau objek tertentu, melainkan untuk semuanya. Penghapusan kelas sosial dan mekanisme pasar yang ditawarkan oleh paham sosialis dan kapitalis adalah kebenaran sekaligus kejujuran dan ketepatan yang terkandung dalam setiap paham ekonomi. Baik secara subjektif maupun objektif. Memang bagi kelompok sosialis, paham kapitalis telah membentuk kelas-kelas sosial. Namun, pada tahap tertentu, paham kapitalis pun tidak menginginkan adanya kelas-kelas sosial. Sesuai dengan cita-citanya untuk membentuk welfare state dan the friendly society, sebagaimana yang dikonsepsikan oleh Adam Smith, mekanisme pasar merupakan tulang punggung ekonomi. Prinsip kebebasan dalam sistem kapitalis ditujukan untuk melindungi hak-hak seluruh kelompok agar dapat ikut bermain di pasar. Lalu bagaimana nasib mereka yang tidak memiliki modal? Di sinilah diperlukannya sikap menerima-atau-menolak tadi. Kaum kapitalis juga menerima tawaran kelompok sosialis yang memberikan kewenangan pemerintah untuk mengatur pasar. Ini bisa kita buktikan dengan melihat kebijakan ekonomi negara kapitalis, seperti Amerika Serikat dan lainnya.

Sikap apa yang ingin saya tegaskan dalam ilustrasi tersebut? Tak lain adalah bagaimana masing-masing paham ekonomi, khususnya ekonomi Islam, bisa melihat cela atau kelemaham paham ekonomi yang lain sebagai suatu kekuatan untuk

\section{La Riba} JURNAL EKONOMI ISLAM

Volume III, No. 1, Juli 2009 
Addiarrahman: Islam dan Pluralitas Paham Ekonomi

membangun dan mencapai tujuan: rahmatan lil 'alamin. Ini memang sedikit utopis karena kita bisa saja mengatakan kalau kelompok kapitalis sendiri tidak akan bisa menerima tawaran yang diberikan paham ekonomi yang lain. Hal ini benar bila dilihat dengan kacamata politik ekonomi. Namun, bila dilihat pada level kebijakan adalah tidak karena terbukti negara-negara kapitalis pun banyak menerapkan konsep yang dikembangkan oleh paham ekonomi sosialis maupun ekonomi Islam. Persoalannya bagaimana dengan ekonomi Islam sendiri? Bukankah selama ini para ekonomnya larut dengan hujatan dan celaan kelemahan yang ada tanpa mau berkomunikasi dengannya. Alih-alih untuk itu, bertransaksi dengan bank konvensional saja dianggap haram dan bertentangan dengan syariat (figh). Oleh karena itu, perlu dilakukan komunikasi. Jika memang ingin mengatakan bunga bank haram karena termasuk riba, bukan berarti kita tidak boleh bertransaksi dengan bank-bank konvensional. Nabi saw. pun dahulu tidak pernah memilih-milih dengan siapa harus bertransaksi. Yang diperlukan adalah bagaimana cara dan prosedur dalam bertransaksi itu. Jika kita menolak bunga ketika bank syariah bertransaksi dengan bank konvensional, maka hendaknya mensyaratkan prestasi yang diberikan adalah dalam bentuk bagi hasil, bukan bunga. Jangan dikatakan dari mana ia memperoleh hasil dari pinjaman yang diberikan. Nabi sendiri ketika bertransaksi dengan orang Yahudi tidak pernah bertanya dari mana ia memperoleh harta. Sikap berburuk sangka bahwa bunga bank itu digunakan untuk kegiatan pembuatan senjata untuk menyerang kelompok Islam juga harus dihilangkan. Di samping karena dilarang oleh syariat, juga sebagai sikap ta'aruf untuk mencapai yang makruf.

\section{Penutup}

Pola hubungan Islam dan ekonomi dalam lintas sejarah Indonesia pada mulanya bersifat dinamis, egalitarian, dan persamaan hak. Pada tahap selanjutnya, tepatnya pada masa kolonial lebih bersikap revolusioner, dan hubungan akar rumput dengan etos nerimo-nya di bawah tekanan rezim Orde Baru yang mengekang segala bentuk aktifitas atau pergerakan kelompok-kelompok agama. Adapun pada era reformasi hingga sekarang lebih bercorak syariah minded, yang ditandai oleh banyaknya gerakan Islam syariat yang muncul ke permukaan. Itu semua dikarenakan kondisi sosial masyarakat Islam. Adapun the new model of silaturabim yang saya tawarkan adalah bagaimana ekonomi Islam mampu berkomunikasi secara terbuka dalam dunia intersubjektif, tidak mencela kelemaham paham ekonomi lain, akan tetapi menjadikannya sebagai kekuatan yang dapat digunakan untuk membangun sistem ekonomi yang kuat. Menghilangkan sikap berburuk sangka terhadap sikap subjektif paham ekonomi lain. Dengan itu, ekonomi Islam akan menjadi piranti yang tidak dikhususkan untuk umat Islam. Ia bukanlah pesaing yang baru bangun untuk memerangi yang telah lama berkembang. Sama seperti kehadiran Islam di tanah Arab pada waktu kejahiliaan merongrong suku Quraisy Arab. Tidak pernah menjadikan "kejahiliaan" bangsa Arab yang menyembah berhala, membunuh anak perempuan, dan lain sebagainya, sebagai ancaman terhadap keberadaan Islam, melainkan sebagai peluang agar Islam diterima oleh seluruh umat, rahmatan lil 'alamin. 
Addiarrahman: Islam dan Pluralitas Paham Ekonomi

\section{DAFTAR PUSTAKA}

Alquran al-Karim.

Abdullah, M. Amin (2002), Studi Agama ; Normatifitas atau Historisitas?, Yogyakarta: Pustaka Pelajar.

Antonio, Muhammad Syafi'i (2001), Bank Syari'ah Dari Teori Ke Praktik, Jakarta: Gema Insani.

Arkoun, Muhammad (1997), Berbagai Pembacaan Al-Qur'an, terj. Jakarta: INIS

Azra, Azyumardi (1998), Jaringan Ulama Timur Tengab dan Kepulauan Nusantara Abad XVII dan XVIII, Jakarta: Mizan.

El Fadl, M. Abou (2004), Atas Nama Tuhan: Dari Fikih Otoriter ke Fikih Otoritatif, terj. Jakarta: Serambi.

Fakih, Mansour (2008), Runtubnya Teori Pembangunan dan Globalisasi, Yogyakarta: Insist Press.

Fealy, Greg, dan Anthony Bubalo (2007), Jejak Kafilah: Pengaruh Radikalisme Timur Tengah di Indonesia, Jakarta: Mizan.

Hardiman, F. Budi (2009), Demokrasi Deliberatif: Menimbang Negara Hukum' dan 'Ruang Publik' dalam Teori Diskursus Jürgen Habermas, Yogyakarta: Kanisius.

F. Budi (2009), Kritik Ideologi: Mengingkap Pertautan Pengetahuan dan Kepentingan Bersama Jürgen Habermas, Yogyakarta: Kanisius.

Heidegger, Martin (1962), Time and Being, translated by John Macquarrie and Edward Robinson, Basil Blackwell.

Hidayat, Komaruddin, dan Ahmad Gaus AF (Ed.) (2006), Menjadi Indonesia; 13 Abad Eksistensi Islam di Bumi Nusantara, Jakarta: Mizan.

Hoetoro, Arif (2007), Ekonomi Islam: Pengantar Analisis Kesejarahan dan Metodologi, Malang: Badan Penerbitan Fakultas Ekonomi Universitas Brawijaya.

Karim, M. Abdul (2007), Sejarah Pemikiran dan Peradaban Islam, Yogyakarta: Pustaka Book Publisher.

Latif, Yudi (2007), Dialektika Islam: Tafsir Sosiologis Atas Sekularisasi dan Islamisasi di Indonesia, Yogyakarta: Jalasutra.

Ma'arif, Ahmad Syafi'i (2009), Islam dalam Bingkeai Keindonesiaan dan Kemanusiaan, Jakarta: Mizan.

McCarthy, Thomas (2008), Teori Kritis Jürgen Habermas, terj. Yogyakarta: Kreasi Wacana.

Nashir, Haedar (2007), Gerakan Islam Syariat: Reproduksi Salafiah Idiologis di Indonesia, Jakarta: PSAP.

Rahardjo, M. Dawam (1999), Islam dan Transformasi Sosial-Ekonomi, Jakarta: LSAF.

Rais, M. Amien (1994), Taubid Sosial: Formula Menggempur Kesenjangan, Jakarta: Mizan.

Rizki, Awalil, dan Nasyith Majidi (2008), Neoliberalisme Mencengkeram Indonesia, Jakarta: E Publishing. 
Addiarrahman: Islam dan Pluralitas Paham Ekonomi

Saeed, Abdullah (2004), Menyoal Bank Syariab: Kritik. Atas Interpretasi Bunga Kaum Neo-Revivalis, terj. Jakarta: Paramadina.

Saidi, Zaim (2005), Kembali Ke Dinar: Tinggalkan Riba Tegakkan Muamalah, Depok: Pustaka Adina.

(2007), Ilusi Demokrasi Kritik dan Otokritik Islam: Menyongsong Kembalinya Tata Kehidupan Islam Menurut Amal Madinah, Jakarta: Republika.

Shihab, M. Quraish (2003), Wawasan al-Qur'an: Tafsir Maudhu'i Atas Pelbagai Persoalan Umat, Bandung: Mizan.

Smith, Donald E. (1970), Religion and Political Development, Boston: Little, Brown and Company.

Tim Penulis MSI UII (2008), Menjawab Keraguan Berekonomi Syari’ah, Yogyakarta: UII Press.

Vadillo, Umar Ibrahim (2005), The End of Economics: an Islamic Critique of Economics, terj. Jakarta: Pustaka Zaman.

Wahid, Abdurrahman (Ed.)(2009), Ilusi Negara Islam: Ekspansi Gerakan Islam Transnasional di Indonesia, Jakarta: Gerakan Bhineka Tunggal Ika, The Wahid Institute, dan Maarif Institute.

(2006), Islamku Islam Anda Islam Kita: Agama Masyarakat Negara Demokrasi, Jakarta: The Wahid Institute.

Woodward, Mark R. Ed. (1999), Jalan Baru Islam: Memetakan Paradigma Mutakhir Islam Indonesia, Jakarta: Mizan.

Yunis, Muhammed (2006), Politik Pengkafiran dan Petaka Kaum Beriman, terj. Yogyakarta: Pilar Media.

\section{Jurnal}

Suharto, Ugi (2004), "Paradigma Ekonomi Konvensional Dalam Sosialisasi Ekonomi Islam," Journal of the Islamic Economic Forum for Indonesian Development (ISEFID), Volume 3. No. 3. 1424/2004.

Hidayati, Noor Azmah (2005), "Politik Akomodasi Orde Baru Terhadap (Umat) Islam: Telaah Historis Kelahiran Perbankan Syari'ah," Millah Jurnal Studi Islam, Vol. IV No. 2, Januari 2005.

\section{Makalah}

Yusdani, “Karena Sempurna Justeru Menjadi Lemah”, Makalah disampaikan pada acara Bedah Kitab Ekonomi Islam yang diselenggarakan oleh Prodi Ekonomi Islam FIAI UII, Kamis, 18 Juni 2009.

\section{Website}

Direktorat Perbankan Syari'ah, Statistik Perbankan Syariah Per-Mei 2009. di download dari www.bi.go.id pada tanggal 16 Juli 2009. 